\title{
On Performance/Performativity Today and Tomorrow
}

\author{
Tereza Turzíková
}

Round table: performance/performativity. Multidisciplinary workshop. Hosted by the Centre for Study of Performativity by the Department of Theatre Studies, Facutly of Arts, Masaryk University. 27 September 2019. The Brno House of Arts - Studio, Brno.

Are the terms 'performance' and 'performativity' only contemporary buzzwords that attempt to mask a crisis in the humanities and art studies? Or are they rather concepts that enable the theoretician to decode contemporary phenomena across multiple academic fields, arts and sciences? These were some of the questions asked during a round table held at the Facutly of Arts, Masaryk University. The Centre for the Study of Performativity invited six speakers from different disciplines to elucidate, share and discuss the current place of performance and performativity in various contemporary studies as well as the potential application of these concepts in both the academic and practical spheres.

The workshop started off with the presentation of an exhaustive theoretical background regarding the use of the term 'performativity' presented by Alice Koubová. In her talk 'The Performative Turn in Philosophy', she spoke about the role of performance in philosophical thinking and outlined challenges such a performative shift in thinking produces. In fact, the performative turn in philosophy has significantly changed the notion of the human subject, forms of thinking, and the institution of philosophy itself. Koubová noted that performativity is not an object of research or just another phenomenon, but rather a transformative theme for many contemporary philosophers, for whom performativity can function as a material force driving us into the action of thinking and thus producing new ways of organizing mental processes. Furthermore, this shift in thinking has an ethical dimension, i.e. performance philosophy forces one to reevaluate personal responsibility in actions and to become more self-critical towards personal biases and presuppositions.

The following talk presented by Csaba Szalo focused on 'Knowledge, Discourse and Performativity in Cultural Sociology'. Szalo introduced the field of cultural sociology as the study of the historical influence of meaning, going on to elaborate on the processes of meaning and value judgement formation in the societal perception of public events. Using the example of Kniefall von Warschau, a historically significant performative act by West German Chancellor Willy Brandt in which he knelt before the memorial to the victims of the Warsaw Ghetto Uprising, Szalo stressed the importance that a public performative act can have for grand narratives and the conceptualization of historical events. Thus, the widespread positive interpretation of Brandt's act was due to its sociohistorical context in which the event-creator 
resonated with the interpretational community through its shared semiological frameworks. Additionally, Szalo pointed out the persistent dialectic of the profane and the sacred within society, and the connection of tensions between these polarities to the ideological dimension of cultural rituals.

The value and meaning society assigns to public performative acts was one of the key topics in the discussion which followed Szalo's presentation. The ethics of performance philosophy as well as the spontaneity of performance and uncontrollability of its consequences were also among the issues raised by the audience. Connecting these abstract mechanisms with the contemporary situation, such as the post-factual and hyperreal world of political events mediated via the Internet and mass media, the first block of the workshop ended on a rather pessimistic note, as the discussions highlighted the necessity of re-thinking ethics in terms of the deconstruction of reality.

The second part of the workshop dealt with performative praxis in non-artistic areas, namely religion and physical training. In her talk 'Performative Dimension of Liturgy', Michaela Vlčková presented liturgy as a form of cult performed by the clergy in the physical presence of believers as the audience. Instead of seeing liturgy as a means of maintaining traditional authorities and symbolic order, Vlčková suggested viewing liturgy through the lens of ritual studies - as a performance, a process with hermeneutical aspects which dynamically forms cultural life and value systems within a community through a shared transformative experience.

The notion of the collective sensation of mutual co-presence and related semiotics, but also connected to purely physical attributes, were discussed in Tereza Konývková's paper on 'The Phenomenal Body as a Means of Performative Formation of Reality'. Her main focus was the Sokol Movement, an organization founded in 1862 by Miroslav Tyrš which played a significant role in the historical development of Czechoslovakia. Konývková applies contemporary theatre and performance theories to archival material, mainly the concepts of phenomenal and semiotic bodies in the work of Erika Fischer-Lichte.

During Konývková's talk and in the following discussion, questions of how national identity is formed via performative behaviour, both repeated and conscious, in public space became points of interest, as did the problem of the duality of aesthetic value and political message in such performances. The example of the 1938 mass gymnastic Sokol performances in Strahov, which took place a few weeks before the Munich Agreement, sparked a discussion on the ethical dimension of such performances. These Sokol performances demonstrated the readiness of Czech men to fight in war and to defend the country, but in the post-war perspective, the impact of such performances must be re-evaluated due to the actual existential threat and terror that millions experienced in WWII.

During the final session, Milan Zvada presented findings from his educational practice in a talk entitled 'Selected Aspects of Performance Studies and Theatre Theory Education in the Global Context'. He noted that performance studies in the Slovak context are not yet grounded enough to become a canonical part of discourses in theatrical or art studies, and therefore a knowledge of the English language is required in order to study the fundamental 
resources. Many phenomena of contemporary artistic praxis, such as contemporary dance, physical theatre and slam poetry, do not have an equivalent in the Slovak language, thus in order to study, describe and conceptualize activities such as these, one has to be familiar with their broad, transnational context. However, from this dynamic and multi-discursive position, performance studies might wield the advantage of being more flexible and adaptable than older disciplines. As Zvada concluded, performance studies is the 'science about everything and nothing'.

Tomáš Ruller offered the perspective of a working artist. Ruller's talk outlined a brief history of performance art, together with notions of how art objects themselves perform in time and space. Following this, he focused on the most significant tendencies in contemporary art, along with the possible future development of the performative arts. Ruller discussed the position of performance in the post-art or even anti-art era. He also introduced the term 'presentation', which might become an adequate substitute of the overused term 'performance'. He stressed the need to engage natural scientists and technology developers into the dialogue about performance in order to avoid reaching a dead end in the discussion between art practitioners and theoreticians.

This would-be dead end, however, is still far ahead, as the journey of exploration of performativity in Czech academic discourse has barely begun. In order to fully explore the potential of performance and performativity in relation to the complex phenomena of today, it is vital to share opportunities like this one. The workshop highlighted certain directions which the study of performativity might take and, more importantly, suggested certain pathways that are yet to be discovered. 